\title{
The Varieties of Secular Experience
}

\author{
GREGORY STARRETT \\ Anthropology, University of North Carolina at Charlotte
}

What keeps religion going is something else than abstract definitions and systems of concatenated adjectives, and something different from faculties of theology and their professors. All these things are after-effects, secondary accretions upon those phenomena of vital conversation with the unseen divine ... renewing themselves in saecula saeculorum in the lives of humble private men.

William James, The Varieties of Religious Experience

We speak of God in a secular fashion when we recognize man as His partner, as the one charged with the task of bestowing meaning and order in human history.

-Harvey Cox, The Secular City

It has become a nearly universal reflex to think about the contemporary Middle East as a region in which secularism is in decline. This is particularly true in countries like Egypt, where the modernist imagination of independence-era socialism seems to have been eclipsed by a grassroots vision of the future as a thoroughly Islamic place, and where the nature of the government's stance with regard to secularism and religion has long been an important question (Winegar 2009; Agrama, this CSSH issue). Since the late 1970s, a decade which saw the Iranian Revolution, the rise of televangelism in the United States, and the beginnings of an extraordinary wave of Protestant conversion in Latin America, it has become popular to produce histories of secularism that will help explain the failure of "the secularization thesis," the idea that with economic development, the spread of education, and the advancement

\footnotetext{
Acknowledgments: This paper was originally delivered at the conference "The Decline of Secularism in Egypt," organized by Tamir Moustafa and Paul Sedra, and sponsored by the School of International Studies at Simon Fraser University, Vancouver, Canada, on 14-15 August 2008. A shorter version was presented at the 2009 meetings of the American Anthropological Association, as part of the session "Religion/Secular Again?" organized by Joyce Dalsheim. My deep thanks to Tamir, Paul, and the other participants in the Vancouver conference for their insight and inspiration. Special thanks to Samuli Schielke, Jonathan Boyarin, John Bowen, and especially Joyce Dalsheim, for their critical perspectives.
} 
of Science, religion was a doomed commodity like pounce pots and butter churns. The moral vision of the popular long-running Star Trek mythology, in which humans as a species have given up religion altogether, seems ever more remote the closer its technological vision becomes. Surprisingly durable, religion refuses to wait quietly in the churchyard for people to visit. Instead, it stands on the street corner denouncing bad behavior and calling the world to salvation. But now the street corner is a television broadcasting satellite (or a cassette tape, or a website), and religion's call has succeeded in ways that no Cold War sociologist or political scientist could have imagined.

Characterizing that success ethnographically, though, proves something of a challenge, both in terms of thinking about the nature of social science, and for thinking about the nature of modernity, Egyptian or otherwise. Consider two case studies. The first, Walter Armbrust's book Mass Culture and Modernism in Egypt (1996), analyzes Egyptian popular culture, media, and educational philosophy over the course of the twentieth century. The second, my Putting Islam to Work: Education, Politics, and Religious Transformation in Egypt (1998), is part of the voluminous literature on the sources of contemporary Islamic movements. The puzzle is this: both Putting Islam to Work and Mass Culture and Modernism cover roughly the same time period, the same broad set of social classes, and the same institutions and processes: literacy, the public sphere, mass media, and the importance of schooling. But despite examining the same subjects and being situated in the same urban setting over the same span of decades, there is no substantive overlap between them. They might as well have been written about different planets.

In my book, Islam takes on a fundamental organizing role in the operation of the modern Egyptian state, and colonizes public culture through the joint competition of the government with broad sections of its political opposition. It is on every page of the book. In Mass Culture and Modernism, on the other hand, there is no index entry for "Islam" or "religion." "Student groups, Islamic" are mentioned on three pages, and specific "Islamists" on five. For Armbrust, the Egyptian public sphere is a thoroughly secular place. For me, it is Islamic to the core.

It's important to note here that I admire Armbrust's work immensely, and within the framework of his research, I think he is not only correct, but also unusually perceptive. His fieldwork was thorough, his data magnificent, his analysis compelling, and his conclusions sound and productive. But I feel the same about my own, very different, take on Egyptian modernity. What gives here? How can two people have written books on the same cluster of subjects, during the same time period in the same place, and said such different things about them? And in the context of such different ways of describing what Egyptian modernity looks like, what can we say about the nature of the secular either as a kind of experience of modernity, or as an object of scholarly attention? 
Taking the Egyptian case as an example, this article examines secularism (and its cognates secularity and the secular), not so much as a failed social project, but as a problematic concept. Reflecting on the on-going scholarly interest in the notion of waning secularity in Egypt, I will suggest that the idea reveals as much about the scholars studying it as it does about a changing social world. Building on the work of British philosopher W. B. Gallie, I will argue that secularism is an essentially contested concept, its meanings fluid, variant, and elusive. This is not merely to observe, as many others have done, that "the 'religious' and the 'secular' are not essentially fixed categories" (Asad 2003: 25), or that "the secular" is so difficult to grasp directly that "it is best pursued through its shadows, as it were" (ibid.: 16). It is to say that the secular's unfixedness is one of its essential features, and that its significance, therefore, is a function of the arguments it generates and the conflicts it organizes, rather than of some phenomenon it purports to describe. Two things follow from this. The first is that the secular's usefulness as an analytical concept is deeply suspect. The second is that growing scholarly interest in studying the secular-Michael Warner (2008: 609) writes about "the emerging realm of secular studies" on the model of religious studies - is a phenomenon that requires our attention.

\section{THE SECULARISM INDUSTRY}

Belief in, or desire for, the eventual inevitable triumph of the secular, and conversely anxiety about its decline, are among the reasons so much ink has been spilled about the "problem" of a religious resurgence. As former secularization theorist Peter Berger put it in 1996, the academic industry devoted to "explaining" fundamentalism in the contemporary world raises an interesting question of what is being explained, and to whom: "The notion [behind this industry] was that ... fundamentalism ... is a rare, hard-to-explain thing. But in fact it is not rare at all, either if one looks at history, or if one looks around the contemporary world. On the contrary, what is rare is people who think otherwise. Put simply, the difficult-to-understand phenomenon is not Iranian mullahs but American university professors" (Berger 2000 [1996]: 38).

So let us begin there, with American university professors and their desire to examine, explain, and define the secular. In his massive 2007 volume $A$ Secular Age, political philosopher Charles Taylor outlines three common understandings of secularism as a sociopolitical phenomenon. In Taylor's summary, one common reading of secularization defines it as the withering of religious practice and belief on the part of individuals and populations. Declining church attendance, the disappearance of traditional beliefs like the idea of hell, the abandonment of rules about birth control or diet, all show that traditional sorts of religious practices have become attenuated in everyday life. Another version of secularization represents it as a withdrawal of religion from the public sphere, a decline of church influence on the law and the effectiveness 
of religious arguments in the public square. Religious traditions come to have less and less to do with divorce law or public education or political mobilization. ${ }^{1}$

Taylor points to the shortcomings in these versions of secularization, and proposes instead that we should understand secularism as a kind of philosophically unstable relativism in which moderns have come to realize the inevitability of choice and difference within modern societies. No longer born into encompassing communities whose religious practice is stable and self-evident, we have learned that whatever choices we make about religious belief and practice, other members of the polity have exercised the same right of choice and have come to different conclusions. "The change I want to define and trace," he writes, "is one which takes us from a society in which it was virtually impossible not to believe in God, to one in which faith, even for the staunchest believer, is one human possibility among others .... Belief in God is no longer axiomatic. There are alternatives" (2007: 3). ${ }^{2}$

The lesson is that each individual should understand that tolerance-allowing the existence of that which we may personally detest - is the ideal solution to the problem of social diversity and the best guarantee of one's own freedom to understand the truth. The historical emergence of the modern public sphere, the market system, and ideas of citizenship link secularism to the mechanics of the modern nation-state, the existence of which, as Benedict Anderson and others have argued, requires a sort of secular civic nationalism that binds citizens to one another across religious and ethnic boundaries. ${ }^{3}$

As a description of a normative system, Taylor's discussion of secularism has merits. But for Talal Asad, such a description is inherently lacking. According to Asad, in characterizing the secular order as an implicit social contract guaranteeing "the horizontal, direct-access character of

\footnotetext{
${ }^{1}$ In the heyday of secularization theory in the United States, the role of churches both black and white in the Civil Rights movement of the 1960s might have provided scholars an early indication that the thesis was flawed, but they seem to have missed it. Taylor seems to have missed its significance as well, for although he mentions other sixties events and popular culture phenomena such as the My Lai massacre, Gene Roddenberry's Star Trek, Anthony Burgess' A Clockwork Orange, New Age Spirituality, and deep ecology, we find that Martin Luther King Jr., the Southern Christian Leadership Conference, and civil rights are absent and presumably irrelevant to the history of his Secular Age.

${ }^{2}$ This formulation is nearly identical to that articulated by theologian Harvey Cox forty years previously. Secularization, according to Cox, "has relativized religious worldviews and thus rendered them innocuous. Religion has been privatized. It has been accepted as the peculiar prerogative and point of view of a particular person or group. Secularization has accomplished what fire and chain could not: it has convinced the believer that he could be wrong, and persuaded the devotee that there are more important things than dying for the faith. The gods of traditional religions live on as private fetishes or the patrons of congenial groups, but they play no significant role in the public life of the secular metropolis" (1966: 2). Cox, once a national intellectual celebrity, whose book sold well over one million copies, is now so well forgotten that in his 874-page tome on secularism, Taylor does not cite his work.

${ }^{3}$ For Talal Asad's perceptive reading of earlier versions of Taylor's theory, see Asad 2003: 4-5.
} 
modern society ... ground[ed] in secular, homogenous time" (2003: 2), Taylor has ignored the conditions of possibility of such normative frameworks, the way that contemporary understandings of citizenship are mediated by specific practices and institutions, including public opinion polls, organized pressure groups, political parties, business leaders, and the mass media itself.

When Taylor says that the modern state has to make citizenship the primary principle of identity, he refers to the way it must transcend the different identities built on class, gender, and religion, replacing conflicting perspectives by unifying experience. In an important sense, this transcendent mediation is secularism. Secularism is not simply an intellectual answer to a question about enduring social peace and toleration. It is an enactment by which a political medium (representation of citizenship) redefines and transcends particular and differentiating practices of the self that are articulated through class, gender, and religion. In contrast, the process of mediation enacted in "premodern" societies includes ways in which the state mediates local identities without aiming at transcendence (Asad 2003: 8).

Asad sees the secular as a way of living in the world, rather than merely an idea about that world or an absence of religion from either individual life or from the public sphere. "What interests me," he writes, "is the attempt to construct categories of the secular and the religious in terms of which modern living is required to take place, and non-modern peoples are invited to assess their adequacy. For representations of 'the secular' and 'the religious' in modern and modernizing states mediate people's identities, help shape their sensibilities, and guarantee their experiences" (2003: 14). For Asad, "the secular" is, in part, a set of concepts, practices, and sensibilities having to do with the way people think about personal freedom and sovereignty in opposition to the constraints offered by religious discourses. The secular plays a part in broader modern projects of power, in which a universalized rationalism exerts itself through necessary violences (ibid.: 59) in the service of the "forcible emancipation from error and despotism. Reason requires that false things be either proscribed and eliminated, or transcribed and re-sited as objects to be seen, heard, and touched by the properly educated senses" (ibid.: 35). As a distinctive feature of modernity, these practices and sensibilities exist prior to the doctrine of "secularism" as a political ideology (ibid.: 15-16).

Following Max Weber's insight that one of the essential features of modernity is its disenchantment of the world, its division of the universe into a domain of the material subject to human reason and technical manipulation, and a domain of the supernatural, a realm of imagination, Asad describes some of the changes in the way the traffic between these realms is managed. He locates the beginning of secularism's success as a political ideology in the nineteenth century, although the seeds of the secular as such were planted earlier in the development of the idea of nature, a sphere of existence whose operation, if not its origin, is legible to human reason in the form of universally applicable laws. The separation between a realm of reason and a realm of the imagination came to be homologous to the difference between truth and 
error, or between logic, on the one hand, and sensibility or passion on the other (ibid.: 23).

By the late eighteenth century, European intellectuals and artists had begun to push back the horizons of the transcendent, the sublime, and the miraculous. They had begun, for example, to trace the origins of artistic creativity to the inner life of the artist rather than to imagine it in the form of the divine muse. At the same time Hegel and his followers developed the idea of History as shaper of human events, replacing the activity of the living God in human experience with a force that was metaphysical but not divine. The world of God and of the supernatural is knowable, if at all, only through revelation or through faith, and it becomes ever less compelling as an explanation either for the operation of the visible world, or for the phenomenology of human experience as other intellectual fields develop. While medicine, psychology, sociology, and history began to provide new sorts of explanations for human experience formerly attributed to God or the stars, to witchcraft or to fate (see also Thomas 1971: 654-55), other experiences came to be viewed through the lenses of artistic inspiration and genius, on the one hand, or pathology and superstition, on the other. Both of the latter categories were read through a "secular" ontology and epistemology in which the borders of the natural and of the self had been reconfigured.

Asad's genealogy of the secular has a profoundly oracular quality, the outcome of a number of brilliant readings linked together in a Frazerian series of association across time and space. ${ }^{4}$ Clearly one of the difficulties with constructing histories and genealogies of concepts such as "the secular" is that, like people, the story of their development takes no single path through the past. If tracing our individual genealogies backwards in time doubles the number of our ancestors each time we ascend a generation (each of us had as many as thirty-two thousand direct forebears sharing the seventeenth-century world with Pascal and Descartes), so intellectual histories have multiple sources, and we can always dispute where and when a particular feature originates. Asad recognizes this problem, of course (2003: 25-26), but

\footnotetext{
4 Asad appears to have found the process frustrating enough that he begins the final section of his first chapter by asking, "So how, finally, do we make anthropological sense of the secular? It is difficult to provide a short answer. Instead, I conclude with two contrasting accounts [from Paul de Man and Walter Benjamin] that relate myth, symbol, and allegory to definitions of the secular" (2003: 62, my emphasis). This conclusion deflects the project of making sense of the secular into yet another set of brilliant and subtle readings. But these do not so much constitute a promised "brief outline of two conceptions of 'the secular' that I see as available to anthropology today" (ibid.: 26), as they describe two possible approaches to social research and analysis, an endeavor which is part of the broader modernist project of which "the secular" is a part. In one of these possible projects, "the secular" promises the unmasking of collective illusions, and in the other the secular is about "exploring the intricate play between representations and what they represent, between actions and disciplines that define and validate them, between language games and forms of life" (ibid.: 66).
} 
does little to address it. His fragmentary genealogy, and thus his view of the nature of the secular remains very much a part of the metanarrative of secularism itself ("the secular" emerges through his writing as having an identity, an origin, a history, and a direction). Other genealogies trace other starting points and other networks of significance.

To give one example, Harvard theologian Harvey Cox was an active participant in developing the secularization thesis in its high form. He wrote in his 1966 bestseller The Secular City that secularization originated neither in the eighteenth-century Enlightenment, or even in an earlier period when Church properties in parts of Europe became subject to seizure by states and temporal elites (one of the original meanings of the term "secularization"). According to Cox, secularization is the moral culmination of Christian history, and should be embraced by believers. Secularization is the progressive assumption of personal and social responsibility in the world. Cox traces the origin of secularization to the biblical stories of Genesis and Exodus, a rather longer pedigree than one meets in Asad or Taylor. The Bible, Cox writes, narrates three great events each of which has resulted in an element of secularization: the creation story of Genesis is the foundation of the disenchantment of nature; the flight of the Hebrews from Egypt gives rise to the desacralization of politics; and the Sinai covenant between God and Moses represents the deconsecration of values.

Phrased this simply, each of these statements appears self-contradictory. But Cox argues that when compared to other religious traditions of the time, the Hebrew conception of creation separates both humans and God from nature. Genesis "is designed to teach the Hebrews that the magical vision, by which nature is seen as a semi-divine force, has no basis in fact. Yahweh, the Creator, whose being is centered outside the natural process, who calls it into existence and names its parts, allows man to perceive nature itself in a matter-of-fact way" (1966: 20). ${ }^{5}$ Likewise, politics is desacralized in the Exodus from Egypt by making history and change, as opposed to enduring nature, the realm of God's action in the world. Despite the tendency of rulers to claim divine right, the prophetic tradition always had the potential to stand in the way of such claims by marshaling a source of moral authority separate from kingship and the state (ibid.: 22). And finally, the Sinai covenant marks both the explicit recognition of the world's multiplicity of gods ("I am the Lord thy God; thou shalt have no other gods before me"), and the rejection of those gods on the part of the Hebrews. This understanding that one

\footnotetext{
5 Asad cites classical historian Jan Bremmer to similar effect, arguing that Hellenic and Christian - not ancient Hebrew - theological styles parted in their view of the distance between God and men (2003: 27). But consistent with the episodic nature of his genealogy, this discussion of the difference between classic and Christian worldviews is nestled within a line of thought referring to the early modern period.
} 
follows a particular god in particular ways while knowing that other gods and forms of worship exist but are off-limits, represents a kind of relativization of consciousness: "Both tribal man and secular man see the world from a particular, socially and historically conditioned point of view. But modern man knows it, and tribal man does not; therein lies the crucial difference. The awareness that his own point of view is relative and conditioned has become for secular man an inescapable component of that point of view" (ibid.: 26-27).

Now, compare this to Taylor, writing four decades later: "We live in a condition where we cannot help but be aware that there are a number of different construals, views which intelligent, reasonably undeluded people, of good will, can and do disagree on. We cannot help looking over our shoulder from time to time, looking sideways, living our faith also in a condition of doubt and uncertainty .... [W] are aware today that one can live the spiritual life differently; that power, fullness, exile, etc., can take different shapes" (2007: 11). ${ }^{6}$

How are we to understand the correspondence between these two descriptions of secularism written some forty years apart, one in the full flower of the secularization thesis by a scholar who urged the faithful to empower their moral vision by seizing the mechanisms of the corporate state, ${ }^{7}$ and the other who is trying to construct a philosophy of pluralism in an age when potentially violent movements of the faithful seem poised to do just that? And how do we make sense of these very different genealogies of secularism?

One answer to both of these questions is that Asad, Cox, and Taylor discuss secularism as a phenomenon insofar as it describes them as secularists. There are, of course, differences. While Asad traces a distinctly high-culture genealogy that describes the experience and outlook of the cosmopolitan scholar as a subject and agent of a modernist political project, Cox and Taylor generalize about the "modern" and the "secular" in ways that homogenize entire periods and populations. "Modern man knows," according to Cox; "We live in a condition," according to Taylor. This latter tactic is the contemporary equivalent to anthropologist Leslie White's division of history into stages based on energy utilization: the long era in which humans used only their own physical energy was succeeded ten thousand years ago by the age of animal domestication, which was replaced in the nineteenth century by the Age of Fossil Fuels, and then in turn by the Nuclear Age (White 1949).

${ }^{6}$ Discussing Walter Benjamin's analysis of Baroque drama, Asad implies that Benjamin might have agreed with Taylor's and Cox's assessment of the relativistic consciousness of secularism: "This world was 'secular' not because scientific knowledge has replaced religious belief ... but because ... it must be lived in uncertainty, without fixed moorings even for the believer, a world in which the real and the imaginary mirror each other" (2003: 64-65).

7 Anti-organizational thinking, according to Cox, "is the modern equivalent of the equally mistaken idea that social problems can be solved only by converting individuals one by one. The truth is that our freedom in the age of organization is a question of the responsible control and exercise of power-vast, towering, unprecedented power. Freedom in such a society is really a kind of power over power" (1966: 151). 
White viewed technologies as elements of global human culture, so that after 1945 the entire world has belonged to the Nuclear Age, even if particular living human beings still depend on dried animal dung for their cooking fires. For Cox and Taylor, a secular age is a secular age because there is "secularism" somewhere in it, not because secularism is a majority philosophy or even a very popular one (see Abu-Lughod 2004; Mahmood 2005: 78).

This perspective, in which the secular enfolds all people, leads to some curious results. One of them is that it always seems difficult to feel a sense of comfort with the security of one's own position within this secular age. At the very same moment that self-described pietists complain about the overwhelming and morally corrupting influence of secularism and its elites, selfdescribed secularists rail about a society swamped by the stultifying cultural influences of religious beliefs and institutions. This simultaneous paranoid expression of weakness and oppression by groups each of whom perceive themselves as embattled minorities with respect to the other, is not uncommon, and is one of the reasons secularism in Taylor's sense is politically productive but emotionally unsatisfying. Social tolerance of both the believer's ignorance and the humanist's immorality results in the believer and the humanist each perceiving suffering and evil as secular tolerance's unavoidable result in allowing the other to thrive.

Such discomfort is part of a broader set of social and intellectual processes that have parallels elsewhere. In Saudi Arabia, for example, the harsh legal imposition of universal religious practice coexists with a paranoid theological style that blames social problems on al-munafiqun (hypocrites), those who pretend to be Muslims, while in their inner hearts they are ready always to betray the faith to its enemies. Clearly the imposition of religious participation creates the threatening category of hypocrite in the first place. Similar polarizing practices run through secular educational discourse nearly everywhere in the world. Public debates about any given national educational system simultaneously promote it as the only hope for social uplift, and criticize it as a morass of incompetence that has betrayed the hopes of the nation. These arguments are robust across time, even as the specific contents and emphases might change. The viewpoints they express exist in what linguists call a state of free variation, their use fluctuating but generally becoming neither more nor less common as the debate proceeds. A structure of contradiction seems to be built into the nature of the concepts - secularism, belief, educationthemselves.

As in the case of educational discourse, "secularism" names a practical or technical field of concern eligible to be theorized and debated. And as in the example of religious hypocrisy, it also points to the result of a social process coming to be perceived as a natural moral object. But both the term "secular" itself and the dichotomy it purports to construct with religion are philosophically problematic. The concept is internally complex, and the 
dichotomy is false. The former difficulty keeps us from using the secular in a consistent way as a normative concept; the latter (to which I will return at the end) might encourage us to abandon its use altogether as an analytical concept.

The term "secular," whether rooting the word "secularism" or the word "secularization," is one of what philosopher W. B. Gallie has called essentially contested concepts, "concepts the proper use of which inevitably involves endless disputes about their proper uses on the part of their users" (1956: 169). Essentially contested concepts cannot by their nature settle into a particular and agreed-upon set of meanings, both because they represent important moral categories in themselves, and because they constitute the terms in which we carry out other debates. Gallie wrote that essentially contested concepts have several characteristics: they are used to establish value judgments or appraisals; they are internally complex, but tend to be perceived as wholes (like "democracy" or "art" or "Christianity"); and their constituent elements can be described in different ways and accorded different priorities of importance as a result of the relative positions and interests of different users. They are used both aggressively and defensively in advancing and supporting diverse positions, and although particular uses of the concept usually refer to the authority of an exemplifying case or tradition, no final agreement on the meaning of the concept can be achieved. This is not necessarily because parties to a debate are mistaken, irrational, or recalcitrant, but because changing circumstances and new bodies of evidence will always unsettle provisional agreement, prompting continual re-evaluations of the concept's internal constituents and the priorities different speakers assign to them. The debates in which they are deployed de-center their meaning, and because of this, essentially contested concepts have a "peculiarly 'open' character" (ibid.: 178).

THE DECLINE OF SECULARISM IN EGYPT?

Academic discussions of the decline of secularism in Egypt take a number of directions. Even Asad, as nuanced as his thought is, cannot help but construct his genealogy of the secular in terms of philosophical discourses nurtured by elites: poetry, literature, philosophy, political theory, law. Linking elite discourses more generally with everyday experience commonly runs them through the modern nation state's apparatuses of power. As we have seen, for Asad secularism is a constellation of mediating processes in which the political eclipses the religious, and the operations of power are meant to be experienced as sovereign individuality (2003: 8, 15-16). A slightly different way of thinking about these connections is to say that secularism is "not so much the abandonment of religion but its ongoing regulation through a variety of state and civic institutions" (Mahmood 2008), or that the secular is a particular kind of entanglement of religion with power, "a process of defining, managing and intervening into religious life and sensibility" (Agrama, this issue). On these readings, we cannot think of secularism in decline in the Egyptian 
context, because secularism is an element of modern governance, and the state is ever more willing and able to regulate the practice of religion. Egypt's state can be viewed as secular insofar as it defines, manages, and otherwise concerns itself with certain kinds of religious thought and practice, not, as Agrama writes, because it meets some metric of adequate distance from religion relative to the "paradigmatic" secular states of Euroamerica. As he points out, even to ask the question about whether the Egyptian state is secular or not is potentially to collapse normative and analytic uses of the term. ${ }^{8}$

As powerful as the work of governing elites and discourses can be, when we look at recent scholarship on the religious and the secular in Egypt, we find that in some of the very best research a different sort of elite discourse is at issue. The self-conscious formation of spiritual elites has been one of the key issues explored by Asad's students Charles Hirschkind (2006) and Saba Mahmood (2005), who have recently produced major contributions to contemporary anthropology. Both have questioned widespread understandings of religion in academic discourse, and have been concerned with broader theoretical issues not specific to Egypt (for Mahmood, the nature of autonomy and its place as a concept in feminist theory; for Hirschkind, the nature of the public sphere as a metaphorical space of both deliberation and discipline). But I would argue that in their ethnographic work both have joined the vast majority of contemporary scholarship on religion in Egypt (including my own) to reinforce, very specifically, the notion that secularism as a valued mode of personal experience is in decline, given the apparently growing appeal of what Hirschkind has called an Islamic "counterpublic." 9

One of the foundations of the influential discourse of secularism-in-decline is an artifact of scholarly methodology, which foregrounds certain practices and events in such a way that they can be read as typical. Another foundation stems from the demands of the contemporary intellectual marketplace, which produces a wider set of discourses in which those practices and events are legible as having broader significance. Ethnographers have long abandoned

\footnotetext{
8 As much as such definitions of the secular help us by replacing a faulty vision of separation with a more accurate vision of entanglement, they do little to distinguish the regulatory interest of the "modern secular state" from the regulatory interest of, say, the medieval Roman Catholic Church, which actively sought to control the religious practice not only of its own members, but of Europe's Jewish communities as well. The latter were informed in the fourteenth century by Pope Innocent IV that they were to follow the law of Moses without the mediation of oral and written Talmudic traditions. This followed several rounds of mass seizure and burning of manuscript copies of the Talmud and other Jewish books. See Starrett 2006: 123-24.

9 This reading is not a criticism, and has nothing to do with the intention of these authors in focusing on the topic of piety movements, or their very nuanced arguments, which explicitly caution readers against taking these practices as general and hegemonic on a broad scale. My argument is a response to the very quality and power of their work and the influence it has wielded in recent discussions of religion in Egypt, readers of which are already predisposed to apprehend deepening piety and broadened public concern with religion as having a kind of directionality. As Foucault has pointed out, the shape of discursive formations is independent of authorial intent.
} 
the quest to describe large-scale societies as integrated wholes. The emphasis over the last several decades has been a closer focus on the parts of the whole: local or virtual groups that can be treated as coherent objects of analysis. In Mahmood's case, the data for her book Politics of Piety was drawn from research at six Cairo mosques, three of which she profiles in detail: the upscale 'Umar mosque in Muhandisin; the working class Ayesha mosque in an impoverished suburb, and the lower-middle class Nefisa mosque. Hirschkind's research in his book The Ethical Soundscape ranged more widely through a public space defined by the circulation of tape cassette sermons, from the preachers who created them to the networks of merchants and young men who distributed, bought, borrowed, copied, and listened to them. These two books are among the most engaging, sophisticated, and important works on Egyptian religious life published in English in the last several years. Each elaborates on a cluster of ideas originally ventured by Asad. Hirschkind and Mahmood examine the conditions of possibility of specific kinds of religious discourse, and how particular modes of engagement with embodied and mediated religious discourses help to fashion individual moral sensibility and the ethical standards of society at large. The individuals they worked with have entered into various kinds of ascetic and disciplinary practice intended to shape their sensitivity to Islam's moral demands, and to allow them to live more fully through embodying pious dispositions. Through mindful prayer, group discussions, intent listening to sermons, and a reconfiguration of everyday life to incorporate pious action, the members of Cairo's piety movements transform their nascent longing to do God's will into enhanced capacities to perceive that will, to carry it out, and to deepen the desire to do both.

The members of these piety movements are what Max Weber might have called aspirational religious virtuosos, individuals who have chosen to enter into relationships of training and mentorship toward the end of spiritual improvement. They represent a self-selected body of ordinary Egyptians for whom religious practice has become particularly salient for any number of reasons. Despite their material ordinariness, they constitute a particular kind of spiritual elite. According to Weber,

Where the religiously qualified virtuosos have combined into an ascetic sect, striving to mould life in this world according to the will of a god ... two things were necessary .... First, the supreme and sacred value must not be of a contemplative nature .... Second, such a religion must ... have given up the purely magical or sacramental character of the means of grace. For these means always devalue action in this world ... and they link ... salvation to the success of processes which are not of a rational everyday nature. When religious virtuosos have combined into an active asceticist sect, two aims are completely attained: the disenchantment of the world and the blockage of the path to salvation by a flight from the world. The path to salvation is turned ... towards an active ascetic "work in this world" (1946: 290). 
Note that Weber is not contrasting religious activity with a secular disenchantment of the world. He is linking them, in that this kind of intense, ascetic religious labor in the present world is a means of attaining the world's disenchantment. It is a sign of secularization. Focused not on the imaginary relations of cause and effect enacted through magic, but on the disciplinary formation of the soul, this is secular labor toward a spiritual goal.

As we might expect of an essentially contested concept, the members of contemporary Egyptian piety movements would reject Weber's labeling of this work as secular, because in their own justifications for it they express a very different understanding of what "secularism" is.

According to the participants, the women's mosque movement emerged in response to the perception that religious knowledge, as a means for organizing daily life, had become increasingly marginalized under modern structures of secular governance. Many of the mosque participants criticized what they considered to be an increasingly prevalent form of religiosity in Egypt, one that accords Islam the status of an abstract system of beliefs that has no direct bearing on how one lives, on what one actually does in the course of a day. This trend, usually referred to by the movements' participants as "secularization" ("almana or "almaniyya) or "westernization (tagharrub), is understood to have reduced Islamic knowledge (both as a mode of conduct and as a set of principles) to the status of "custom and folklore" ('ada wa fulklur). While a handful of mosque participants used the terms "secularization" and "westernization" to refer to specific events in recent Egyptian history, most employed the terms more loosely to describe a transformative force beyond their control that was corrosive of the sensibilities and habits of a certain kind of religious life (Mahmood 2005: 44).

"The state and society," one woman said, "want to reduce Islam to folklore, as if Islam is just a collection of ceremonies and customs, such as hanging lanterns from doorways or baking cookies during Ramadan, or eating meat [on feast days]. Mere ceremonies without any bearing on the rest of life" (ibid.: 49), like forms of popular entertainment or ways of displaying ethnic and cultural identity (ibid.: 48). Such a transformation, which they are trying to reverse, "is the project of the government and the secularists.... People may not even know that they are doing this, but in fact what they do in actual behavior is to turn religion into no more than a folklore custom" (quoted in ibid.: 50). From the point of view of these women, secularism is far from being in decline. Instead, it represents a hegemonic set of structures, practices, and institutions that must be actively resisted.

This reaction against Islam as mere folklore rather than a living concern understood and practiced for explicitly articulated reasons is common to piety movements elsewhere (Deeb 2006). ${ }^{10}$ Even if we think about Islam as the abstract system of beliefs derided by pietists, the manner in which those

${ }^{10}$ In Deeb's Lebanon, though, the folkloric nature of everyday Islam was taken to be the result of the backwardness of the uneducated and underprivileged rather than the work of government and secularists. 
beliefs are understood, debated, rationalized, and developed represents secularization in the sense that both Harvey Cox and Charles Taylor put forward. They represent the explicit development of moral and logical justifications for practices previously taken-for-granted, in the context of an understanding that, if there are other ways of being human, one ought to be able to defend one's own preferences (Eickelman 1992; Deeb 2006).

Mahmood's case study is motivated by a desire to answer theoretical questions about agency, autonomy, and the strengths and weaknesses of different strains of feminist theory in confronting the rise of Islamic piety movements around the world. But the very strength of her ethnography of aspirational virtuosos invites us, particularly in the context of the ocean of literature that has been produced on the Islamic revival over the last generation, to perceive their practice as rather more typical than it really is. For obvious reasons neither Hirschkind's cassette devotees nor Mahmood's mosque participants can be enumerated in any simple sense, and so the demographic extent of these movements is unknowable and impressionistic. Even so, it could be argued that in order to understand Islam in Egypt today, and thus to understand the apparently wilting career of secularism in the country-wilting from the point of view of the non-pietist, at least-it is precisely this spiritual elite, the most active members of the Islamic revival, to whom we should attend.

Psychologist and philosopher William James, in his Gifford Lectures to the University of Edinburgh in 1901-1902, later published as The Varieties of Religious Experience, argued precisely for this point of view. Formulating his ideas in the same era as Weber, James wrote that studying religion as a psychological phenomenon required focusing on the records of its most intense experience. Religion can be understood best not by attending to religious institutions or traditions, but by examining individuals who have recorded the most direct and powerful experiences of encounter with the divine.

I speak not now of your ordinary religious believer, who follows the conventional observances of his country, whether it be Buddhist, Christian, or Mohammedan. His religion has been made for him by others, communicated to him by tradition, determined to fixed forms by imitation, and retained by habit. It would profit us little to study this secondhand religious life. We must make search rather for the original experiences which were the pattern-setters to all this mass of suggested feeling and imitated conduct. These experiences we can only find in individuals for whom religion exists not as a dull habit, but as an acute fever rather.... such individuals are 'geniuses' in the religious line (1958: 24).

The key to understanding the nature of religious life, for James, was to study "the acute religion of the few" rather than "the chronic religion of the many" (ibid.: 101). The spiritual goals sought by members of piety movements are what James called the "volitional type," in which "the regenerative change is usually gradual, and consists in the building up, piece by piece, of a new set of moral and spiritual habits" (ibid.: 169). 
Seen from one sort of secularist standpoint as potential harbingers of the country's future, the piety movements described by Hirschkind and Mahmood, and the manifold processes and institutions I described in Putting Islam to Work, including enrollment increases in religious studies programs at university, the spread of private Islamic schools, the increased availability of religious publications, commodities, and broadcasts, and the very purposeful development of religious discourses as measures of social control, can appear to express a growing religious hegemony in public space, even if portions of that growth can be described as "fragile and unstable accomplishment[s]" (Hirschkind 2006: 108) rather than as "pervasive, persistent, and normal" (Starrett 1998: 90). These piety movements have become hegemonic in the sociological imagination even if they may be partial, limited, and contested from the perspective of those engaged in them. They are contested from one direction by the more explicitly political elements of the Islamic movement, who are not satisfied with the cultivation of piety but who wish to foster sociopolitical change from above through the application of bodies of legislation alleged to be "shari'a". They are contested from the other direction by some elements of the official religious establishment of the Egyptian state, as well as by the country's intellectual elite.

According to Weber, religious virtuosos can exercise powerful influence over the practice and ideology of laymen, the result of which is at least an implicit conflict with bureaucratized forms of religion which seek to organize the piety of the masses in their own way (1946: 288-89), even though in this case, Mahmood argues, the values promulgated by the women's mosque movement are those of the hegemonic patriarchal status quo. The point here is that, if one way of conceiving of secularization is as a transfer of resources and of moral and cultural authority away from official religious institutions, we encounter here the paradox of secularization in the absence of secularism (the withering away of belief). Mahmood talks about this change by pointing out that "Theological and doctrinal issues that were once the provenance of male religious scholars are now debated by ordinary women in the context of mosque lessons modeled to some extent on protocols of public address and modern education ... where they openly discuss how to render even the most intimate details of their lives in accord with standards of Islamic piety" (2005: 55).

The state and the county's cultural elites respond both by furthering the discourse of the appropriateness and necessity of interest in the Islamic heritage, ${ }^{11}$

11 Clearly "the state" is not a unified entity, but an organized collection of internal interest groups, composed of individuals drawn from the broader society. What this means is that government encouragement of particular kinds of religious practice are sometimes sincere, sometimes consciously pandering, and always liable to produce unintended consequences. As Nandy writes, "My belief is that states ... usually muddle through a series of crises on a day-to-day basis. The kind of agency and coherence often imputed to these impersonal entities is usually a projection of our inner 
and also by hedging their bets, calling for moderation in the name, not of secularism, but of "normality." Hirschkind quotes an editorial from the Englishlanguage al-Ahram Weekly: "we should restore mosques once again to their proper function as places of worship, and provide young people with plenty of other accessible leisure activities, so that they can live like normal young people, studying or working in the morning, going to their place of worship to pray, and then in their leisure time going to the cinema, theatre or library, or taking part in their favorite sport" (quoted in Hirschkind 2006: 126). ${ }^{12}$ The state and its various cultural elites have long maintained that any activity on the part of Egypt's masses should have positive purpose (hence the mention, above, of salutary secular pastimes like cinema, theatre, and library, from each of which one might learn to be a better person). This was the long-range goal of modern forms of education as articulated during the whole of the twentieth century, whether conceived in religious or non-religious form (Armbrust 1996; Starrett 1998).

But the discourses of self-improvement deployed by political, economic or spiritual elites do not always match the experiences or desires of everyday Egyptians. Samuli Schielke (2006; 2008a; 2008b; 2009; n.d.), for example, in what might be posed as an antidote to the kind of narrowly focused piety research approved by William James, has written about the everyday lives of young rural Egyptian men, showing that, contrary to the goals of the government's encouragement of theater and library patronage, and contrary to the goals of Islamic revival movements, young men in the country's innumerable villages have different sets of priorities for how to use their time: "With all their differences, football and hashish both present to young men in the village a very different framework of entertainment than the trend of religious video clips does. Along with other forms of entertainment popular among young men such as television, cafes, music, weddings, joking, walks, flirting, internet chat, and pornography, they are essentially seen as ways to escape boredom and not measured by their purposefulness" (Schielke 2008a: 253). ${ }^{13}$

needs and anthropomorphic fantasies of a parental state; such feel-good attributions are a tribute to our trusting nature rather than to political acumen" (2007: 111).

12 The implication is that the Islamic movements' insistence on persistent and pervasive forms of piety represents a kind of alienation foreign to Egyptian experience. Here one cannot help but recall Marx's vision of a communist society in which people are not forced into artificial kinds of specialization, but "society regulates the general production and thus makes it possible for me to do one thing today and another tomorrow, to hunt in the morning, fish in the afternoon, rear cattle in the evening, criticize after dinner, just as I have a mind, without ever becoming hunter, fisherman, shepherd or critic" (Marx 1978: 160). In the Egyptian case, this authentic humanity is conceived by secularist elites to be at one with the interests of the state.

${ }^{13}$ See Armbrust 1996 for perceptions of the "meaninglessness" of popular forms of entertainment. 
Schielke does not deny the influence of Salafi religiosity in the countrysideindeed, he attributes to it a near-monopoly as a style of public religious discussion-but he does show that the concerns of young people do not necessarily respond to it in any strong way. Their attempt to escape boredom "does not defy moral or religious values, but ignores them" (ibid.: 262). Many rural youth have experimented with piety movements only to drop out when their discipline became too demanding. A surprisingly high number of young men not only consume media, but also produce it, writing fiction and fantasizing outside the confines of religious ideology, constructing tales of secular adventure for themselves in which they escape the confines of lives they find nearly unbearable. "Neither the will to live virtuous lives," Schielke writes, "nor the dichotomy of secular and Islamic versions of virtue, can be taken for granted if we are to understand how people experience their lives in an age of religious revival, global fantasies, and frustrated aspirations" (ibid.: 268). Instead, moral practice responds not only to the strictures of Salafism, but also to "social customs and values, personal desires, and economical pressures, a balance in which the weight of different constituents can change depending on the social context of a practice, the time of the year, and one's personal biography" (Schielke 2009: 12). In striving to understand religion and the secular in contemporary Egypt, we should pay at least as much attention to Ramadan soccer matches (2009), the sensual pleasures of saints-day festivals (2008b), and the "moments of uncertainty and skepticism that can at times be hidden behind a performance of certainty" (n.d.: 5) as we do to aspirational virtuosos and state policy. Otherwise, we will be unable to comprehend either the complexity and inherent ambiguity of Egyptian moral orders, or the tendency of social research generally to characterize those orders in simple terms of ascent and decline.

WHAT HAS ANY OF THIS TO DO WITH SECULARISM?

The kind of secularization implicit in the transfer of cultural capital from traditional religious scholars to lay intellectuals and even the educated public at large has been noted by dozens of scholars over the last two decades. But as momentous as it is (even if Taylor tells us that this is not really what secularism is about), this change is only one example of the processes through which things we might identify as religious and things we might identify as secular are intertwined, and the sense in which they cannot be seen as representing two players in a zero-sum game, but players whose moves not only counter, but often actively advance the interests and successes of the other. Like Schielke, Walter Armbrust in some of his more recent work has focused on topics like the "Christmas-ization of Ramadan," the transformation of a pillar of Islamic practice into a long consumerist season of Islamic-themed secular pleasures (2005). Consistent with the views of Cairo's piety movement, this transformation might seem to indicate a growth rather than a decline of 
secularism in the public sphere, but from an analytical perspective it only further muddies categorical distinctions between the secular and the religious while sharpening the arguments about both, and bringing us back to the general unease characteristic of a "secular age."

Hirschkind provides two telling quotes from Cairenes on the subject of this unease, specifically perceptions of contemporary noise pollution. They match the sorts of complaints I described above, about how difficult it is to live a quiet life in modern times, unaccosted by the noisy demands of those who do not share one's world view. Secularists complain about the intrusion of religion into the public sphere, while the pious complain about the intrusion of secular immorality. Both argue that public spaces are uniquely unwelcoming to their perspectives. One Egyptian interviewed in 2005 by the BBC told correspondent Sylvia Smith,

My neighborhood sounds like a rock concert each morning [because of the multiple, amplified calls to prayer from local mosques] and has become nearly uninhabitable. I now sleep with earplugs. Compounding the problem is that other faiths are not granted the same privilege. Christians are forbidden to ring bells, broadcast Christmas carols or religious songs. As in many Islamic states, religious freedom is suppressed and the verbal onslaught each morning is merely one of many powerful tools used to dominate other faiths. When I was young I used to enjoy the lone, clear voice calling us to prayer but no longer (quoted in Hirschkind 2006: 125-26).

Preacher Muhammad Hassan, on the other hand, focused in one of his sermons on the overwhelming problem of Godless noise: "We all know that cursed [music] tape 'Luna.' It has sold more than eighty million [sic] copies, and there is nowhere you can go to escape from it. Young people listen and sing the words. It puts these words full of illicit desires into the mouths of the young people until they go out and commit sins. It pulls them to the disco, boys and girls, where they engage in evil, filthy dancing. Muslims! Our young Muslim sons and daughters!" (quoted in Hirschkind 2006: 127).

The extraordinary recent expansion of mass media in Egypt and in the Middle East more broadly is one of the reasons for this disquiet on the part of the pious, but also a reason to stand back and think about what a "decline of secularism" might mean. When music videos, foreign news programs, serials, movies, and other programs are widely available through satellite TV and the Internet, the range and volume of "secular" entertainment and information is greater than ever. The Egyptian public sphere, however it is measured, has grown multiple times larger than it was a generation ago. So if, for example, the title list at the annual Cairo book fair has become more religious over time (it has), does that mean that Egypt is less secular than it was before one could effortlessly view videos of Nancy, Haifa Wahbe, Miriam Fares, and other bare-shouldered Lebanese chanteuses on ArabSat or YouTube? In a conceptual space that is ballooning with secular content and in which Islamic practice is being transformed into folklore, the perception 
of secularism in decline has a very specific sense: people who define themselves as secularists are concerned about their influence in specific local social domains in which they have traditionally held power.

Lila Abu-Lughod, for example, writes about Egyptian director Muhammad Fadil, who

actually blamed television's compromises for the spread of extremism. He said in an interview, "Egyptians have always been a religious people, without any outside interference, and without the excessive religiosity that is now present in the mass media. It is as if those responsible feel guilty, and thus the mass media feel the need to assert their religiosity. Why?" ... When I asked him whether he thought extremism should be confronted through media, he responded harshly, and with support for government policy that was uncharacteristic of this social critic who was known for targeting the government's neoliberal economic policies ... . It was too late, he argued. "Today as a citizen I don't feel safe walking in the street. I'm even afraid to go to the theater or cinema. The situation has degenerated so much that it can no longer be confronted by art.... It is beyond being dealt with by words; it has to be dealt with forcefully with repressive security" (2004: 173).

That secularism might be defended by the repressive power of a state whose official religion is Islam, and which has arguably furthered in many ways the very religious developments he fears, seems not to have struck Fadil as particularly problematic. The notion that the Egyptian state is "secular" in any important sense is something I have spent a good deal of space arguing against (1998; 1999). ${ }^{14}$ I have proposed, instead, that the discourse of the secular has ordinarily been used-for example, in widespread news coverage during the 1980s and 1990s about Islamist groups battling "Egypt's secular government"- as an element of self-definition, and a way to talk about the common interests of Egyptian and foreign governments (1998: 16, 234). But why do we feel the need to make one sort of argument or the other in the first place, to characterize something in or about Egyptian life or public culture as either secular or not? Can we even agree on what we are talking about? Was Nasser's 1961 nationalization of al-Azhar university a bold secularizing move, as Mona Abaza (1994: 34-35), among many, many others, has argued? Or was it, instead, an infusion of the governing structure with religious concern, responsibility, and resources, a bold move in the direction of a politics that cannot do without controlling and deploying religious institutions and ideologies, as I might argue? Does redefining the secular as an issue of state control over religion rather than separation from religion bypass this problem, or does it merely create new ones (e.g., if the government of Iran exercises more control over

\footnotetext{
14 This violates Agrama's (this volume) very perceptive point that asking this sort of question collapses the analytical and normative senses of "secular" by subjecting the Egyptian government to a comparison of secular adequacy with the "paradigmatic" secular states of the west. But in my view, it is not the question or the comparison that collapses analytical and normative senses of secular, but that secularity has no meaningful analytical sense at all. Asking the question cannot have any other meaning than establishing a moral position regarding the answer.
} 
religion than the government of the United States, does that mean that Iran is a more secular place than the United States?) More broadly, when we distinguish between religious and secular enterprises, can we avoid taking one side or the other? And once we choose a position, what do we have to overlook in order to pursue the argument?

\section{ONCLUSIONS}

The difference is between recognizing that one has, and presumably will continue to have, opponents, and recognizing that this is an essential feature of the activity one is pursuing (Gallie 1956: 192).

If secularism is an essentially contested normative concept in Gallie's sense, and if actual cases of "secularism," "secularity," and "the secular" as social, political, or symbolic systems display such wide variation, we need to ask ourselves what utility the secular has as an analytical concept. American secularism defends a Jeffersonian "wall of separation" between church and state by defining the phrase "In God We Trust" on coinage as a non-religious statement (Sullivan 1995; 2005). Turkish secularism not only operates the Islamic establishment but also requires religious instruction in public schools, at the same time that it organizes itself around the obligatory public ritual memorialization of a long-dead culture hero (Özyürek 2006). Soviet secularism initiated a stunningly energetic campaign of official atheism only to find itself compelled to invent a whole range of life-cycle rituals in which the State and the People took the place of God (Froese 2008). French secularism mandates that the state own and maintain important Roman Catholic cathedrals but does not allow the display of religious images in schools (Bowen 2006). Like many other cultural categories - marriage, property, religion — secularism's definition must be drawn in terms "so general, in fact, that whatever force it seems to have virtually evaporates" (Geertz 1973: 40).

That generality, one of the sources of its essential contestedness and imprecision, may derive from secularism's utter dependence on the concept of religion. ${ }^{15}$ Conceptually, the secular is always a term of contrast: it is what is left over when we create and populate the category of religion. Taxonomists call such leftovers "paraphyletic categories." A paraphylum is a category formed by the objects left over in the construction of another category. The category "invertebrate," for instance, is constructed by defining the class of vertebrates, animals with backbones, leaving behind a paraphylum of creatures

\footnotetext{
15 I agree with the argument deployed by Mahmood (2006), Agrama (this issue), and others that the practices and institutions they see as part of "the secular modern" are responsible for defining particular kinds of religious thought and practice as legitimate, genuine, or legal, and even what counts as religion as such. I have made much the same the argument myself (1998; 1999). But here I am referring not to social or historical processes, but to the quotidian taxonomic and cognitive processes that structure the way people make judgments about what secularity is.
} 
as diverse as earthworms, mosquitoes, crabs, octopuses, and coral, which have nothing in common except their spinelessness.

Insofar as the secular is only used as a concept in contrast - implicit or explicit - with "the religious," it cannot stand on its own as the label for events, ideas, objects, or behaviors that share any characteristics aside from being "non" religious. And in that broad universe of the secular, one might identify at least three aspects of this "non" status. First, there are events, actions, ideas, or objects which harm or diminish religion (the anti-), such as legal restrictions on religious practice, the burning of sacred texts, the suppression or murder of religious specialists and destruction or desecration of places of worship, or propaganda directed against religious ideas, values, or traditions. Second, there are events, actions, ideas, or objects unconnected or irrelevant to religion at all (the neutral, or "merely non-"). This category is obviously relative to particular religious traditions, and might even be denied as a possibility by ideologues who claim that, for such-and-such a tradition, no part of life or aspect of the cosmos lies outside the aegis of religious authority or interest (food taboos, sexual mores, sartorial or grooming habits, scientific knowledge, entertainment choices, etc.) And third, there are events, actions, ideas or objects which are homologues of religion (the pseudo-), such as civic or "secular" ritual, "sacred" symbols such as national flags or monuments, or charismatic individuals such as politicians or pop stars who command identifications and behaviors on the part of their followers similar to those attending the lives and activities of saints, holy men, or minor deities. One can imagine adding other or finer sorts of distinctions, such as the Egyptian pietist definition of secularism as a transformation of religion into folklore, a preservation of empty form halfway between suppression and irrelevance. Add Weber's disenchanted religious asceticism and Cox's secularizing partnership of men working to further God's plan, and we might want to argue that all this complexity serves us well by enriching our appreciation of what the secular can and might be. Or, we might look in a different direction altogether for the significance of the secular.

It is not likely that the majority of Egyptians, any more than the majority of North Americans, experience their lives neatly divided between secular and religious concerns, let alone defining themselves as living one or the other kind of life altogether. The categorization of the world into the secular and the religious is a peculiar kind of practice that serves a purpose for particular kinds of people (Dalsheim, this issue; and forthcoming). Anthropologists have long pointed out that tribal genealogies are usually less descriptions of biological or even social reality, than they are strategic statements expressing the political position and capabilities of the notable men who articulate them (Bourdieu 1977; Shryock 1997). Secularism fulfils a similar function for those who define themselves in its terms. Such definitions and genealogies justify an order in which a particular kind of elite finds its privileged place. 
The tribal genealogy is articulated in order to claim specific kinds of power and legitimacy. Secularism as an explanation of or a label for particular features of contemporary society asserts the legitimacy of individuals, groups, and institutions that do not or cannot find common cause with phenomena that come to be labeled as "communal" or "religious." In an important sense, this fact invites us to read books like Taylor's A Secular Age not as philosophy or history, but primarily as foundational myth and as autobiography. ${ }^{16}$

The Indian intellectual Ashis Nandy has written thoughtfully about the place of the secularist in a world in which secularism seems to be in decline. "Any plea for nonmodern, traditional, or people's knowledge in public life," he says, "arouses the fear that such knowledge might lead to large-scale displacement or uprooting in the domain of intellectual work, that the familiar world of knowledge might shrink, if not collapse and, in the new world that may come into being, there would be less space for the likes of us. What Sigmund Freud says about the inescapable human fantasy of immortality — our inability to visualize a world without us - applies in this case, too. Many of us are haunted by the question 'What will be my place in a nonsecular or nonmodern world?'” (2007: 109). Recalling that the majority of deaths during twentieth-century genocides were committed by states that did not define themselves according to religious values (Nazi Germany, Stalinist Russia, Mao's China, Pol Pot's Cambodia), Nandy is skeptical of intellectuals like Egyptian television director Muhammad Fadil, who assert that secular intolerance might be the answer to the perceived threat of religious hegemony.

The high culture of democracy in modern, metropolitan India today has as its substratum a deep fear of the people and a vague, anxious suspicion that much of the citizenry might not need vanguards, experts in multiculturalism, or ideologically driven, politically correct, Orwellian thought police. But saying so is obviously an unpopular stance; it smacks of class betrayal. How can there be a healthy, humane ... polity where the concepts and categories that characterize the mainstream, global, middle-class culture become superfluous or secondary? Where will we and our respectable friends in respectable universities then be? Hence, the other prescription the spin doctors of secularism ... end up recommending - greater use of the coercive apparatus of the state to ram the ideology of secularism down the throat of the ... citizenry and to promote an even more systematic use of the ideology as a principle of exclusion (ibid.: 116). ${ }^{17}$

\footnotetext{
16 One of the most interesting elements of the review process of this paper has been that, although the reviewers argued with me vigorously about my readings of Weber, Taylor, and Asad, not a single one made any substantive comment about the only Western theistic reading of secularism discussed here, that of Harvey Cox. From the standpoint of the academy, a theological origin for the secular might not be eligible to be taken seriously, even though — or perhaps particularly because - similar arguments have been made by other authors (see, e.g., Asad's 2008 summary of the work of Marcel Gauchet) to ground notions of the superiority of Christian over Muslim civilization.

${ }^{17}$ Gallie warns that tactical misunderstandings of the nature of contestedness might be healthier than philosophical clarity. "So long as contestant users of any essentially contested concept believe, however deludedly, that their own use of it is the only one that can command honest and informed
} 
Returning to Gallie's idea of essentially contested concepts, we should remember that one of their central features is that they are used to make value judgments, and value judgments emanate from social, cultural, moral, and political frameworks, not necessarily scholarly ones. Secularism is ultimately a normative concept, and we make a mistake if we treat it as an antytical one. Every time we contrast secularism and religion, we implicitly make a choice of sides between the two, and our implicit choice arises from our own positions within local, national, regional, and global systems of social organization and discourse. This is not an invalid thing to do. We all need to be able to argue for the appropriateness of particular ways of organizing our own social worlds. But treating normative concepts as analytical ones not only results in conceptual confusion, it distracts us from the larger question of our own place in the intellectual systems we construct.

Gallie felt that the recognition of a normative concept as essentially contested was a positive step, since it freed debating parties of the necessity to demonize each other, and allowed for a more productive discussion:

Recognition of a given concept as essentially contested implies recognition of rival uses of it (such as oneself repudiates) as not only logically possible and humanly "likely" but as of permanent potential critical value to one's own use or interpretation of the concept in question; whereas to regard any rival use as anathema, perverse, bestial or lunatic means, in many cases, to submit oneself to the chronic human peril of underestimating the value of one's opponents' positions. One very desirable consequence of the required recognition in any proper instance of essential contestedness might therefore be expected to be a marked raising of the level of quality of arguments in the disputes of the contestant parties. And this would mean prima facie, a justification of the continued competition for support and acknowledgement between the various contesting parties (1956: 193).

This sounds very much like the way Cox and Taylor characterized secularism itself, as a state in which we recognize the legitimacy of human difference even as each one of us consciously chooses to reject all but a narrow segment of the great arc of human possibility (the image is Ruth Benedict's). What Gallie might add to this, if we let him, is the notion that this rejection is a qualified one, justifying a continued competition and sharpening of the quality of particular alternatives.

Perhaps unfortunately, extending this progressive logic of the essentially contested concept from the comfortable fire-lit precincts of the Aristotelian Society of London to the broader world of Cox's Secular City or Taylor's Secular Age — to the scale of human religious diversity at large — can only be

approval, they are likely to persist in the hope that they will ultimately persuade and convert all their opponents by logical means. But once let the truth out of the bag-i.e., the essential contestedness of the concept in question - then this harmless if deluded hope may well be replaced by a ruthless decision ... to damn the heretics and to exterminate the unwanted" (1956: 193-94). 
metaphorical. The diversity of real viewpoints in the world is such that some of them do reject the premise that such debate is legitimate, and do regard alternatives as "anathema, perverse, bestial or lunatic," whether these are the viewpoints of Salafi ideologues or professional atheists. This is not an empirical statement claiming that some of us do not yet belong to the secular age. It is a critique of the internal contradictions of the concept itself, which would seem to imply that the only legitimate position with regard to secularism is the embrace of secularism, which allows us all to acknowledge and tolerate the existence of people who do not embrace our ideas and values.

The strong intellectualist and elitist quality of theories of the secular stems in part from the relationships of objectification that structure our encounter with them. Our own relationship to the secular makes it look simultaneously like a triumphant moment in a long philosophical debate, in which we have all finally achieved a breakthrough insight, and also like a coherent natural object that we can describe without admitting that we have vested interests in the way it is characterized (Bourdieu 1977). Although the secular might not be altogether useless as a concept, there is a big difference between being not altogether useless, and being enlightening. ${ }^{18}$ Having no stable meaning, and bearing the meaning it does nearly entirely in its polythetic contrasts to another problematic category (religion), the use of "the secular" as an analytical concept retains only the ability to minimize the complexity of real lives, to obscure our understanding of contemporary history (Egyptian and otherwise), and to mislead us into thinking that we might someday experience the luxury of escaping from our interpretive rivals.

\section{REFERENCES}

Abaza, Mona. 1994. Islamic Education: Perceptions and Exchanges. Indonesian Students in Cairo. Paris: Cahier d'Archipel.

Abu-Lughod, Lila. 2004. Dramas of Nationhood: The Politics of Television in Egypt. Chicago: University of Chicago Press.

Armbrust, Walter. 1996. Mass Culture and Modernism in Egypt. Cambridge: Cambridge University Press.

18 One reviewer of this article asked rhetorically, "Isn't the author by implication arguing that we should abandon, along with secularism as a general concept, the concepts of democracy, art, Christianity, belief, education and many more besides? What, in fact, would we be left with as general concepts? Is there nothing worth arguing for (or even about)?" Abandoning these other categories is neither necessary nor possible now, as we secularists have not really taken categories like "Christianity" or "democracy" or "art" seriously as anything other than normative concepts for decades. We do not expect that labeling an action, an object, an event, or an institution "democratic" or "Christian" actually teaches us very much about it. The trick, from my point of view, is to recognize that "the secular" falls in the same company, and that we should stop pretending that it has much utility except as a normative concept, which all are welcome to argue about in perpetuity from within its varied traditions (separation, extermination, entanglement, laicite, folklorization, asceticism, etc.), each of which will necessarily result in very different kinds of discussions. 
Armbrust, Walter. 2005. Synchronizing Watches: The State, the Consumer, and Sacred Time in Ramadan Television. In Birgit Meyer and Annaleis Moors, eds., Religion, Media and the Public Sphere. Bloomington: Indiana University Press, 207-26.

Asad, Talal. 2003. Formations of the Secular: Christianity, Islam, Modernity. Stanford, Calif: Stanford University Press.

Asad, Talal. 2008. Reflections on Blasphemy and Secular Criticism. In Hent de Vries, ed., Religion: Beyond a Concept. New York: Fordham University Press, 580-609.

Berger, Peter. 2000 [1996]. Secularism in Retreat. In John L. Esposito and Azzam Tamimi, eds., Islam and Secularism in the Middle East. New York: New York University Press, 38-51.

Bourdieu, Pierre. 1977. Outline of a Theory of Practice. Cambridge: Cambridge University Press.

Bowen, John. 2006. Why the French Don't Like Headscarves. Princeton: Princeton University Press.

Cox, Harvey. 1966. The Secular City. New York: Macmillan.

Dalsheim, Joyce. forthcoming. Unsettling Gaza: Secular Liberalism, Radical Religion, and the Israeli Settlement Project. New York: Oxford University Press.

Deeb, Lara. 2006. An Enchanted Modern: Gender and Public Piety in Shi i Lebanon. Princeton: Princeton University Press.

Eickelman, Dale F. 1992. Mass Higher Education and the Religious Imagination in Contemporary Arab Societies. American Ethnologist 19, 4: 643-54.

Froese, Paul. 2008. The Plot to Kill God: Findings from the Soviet Experiment in Secularization. Berkeley: University of California Press.

Gallie, W. B. 1956. Essentially Contested Concepts. Proceedings of the Aristotelian Society of London 56: 167-98.

Geertz, Clifford. 1973. The Impact of the Concept of Culture on the Concept of Man. In The Interpretation of Cultures. New York: Basic Books, 33-54.

Hirschkind, Charles. 2006. The Ethical Soundscape: Cassette Sermons and Islamic Counterpublics. New York: Columbia University Press.

James, William. 1958 [1902]. The Varieties of Religious Experience. New York: New American Library.

Mahmood, Saba. 2005. Politics of Piety: The Islamic Revival and the Feminist Subject. Princeton: Princeton University Press.

Mahmood, Saba. 2006. Secularism, Hermeneutics, Empire: The Politics of Islamic Reformation. Public Culture 18, 2: 323-47.

Mahmood, Saba. 2008. Secular Imperatives. Post on the SSRC website "The Immanent Frame": http://blogs.ssrc.org/tif/2008/05/07/secular-imperatives/ accessed 7 Jan. 2009.

Marx, Karl. 1978 [1846]. The German Ideology. In Robert C. Tucker, ed., The MarxEngels Reader. 2d ed. New York: Norton, 146-200.

Nandy, Ashis. 2007. Closing the Debate on Secularism: A Personal Statement. In Anuradha Dingwaney Needham and Rajeswari Sunder Rajan, eds., The Crisis of Secularism in India. Durham, N.C.: Duke University Press, 107-17.

Özyürek, Esra. 2006. Nostalgia for the Modern: State Secularism and Everyday Politics in Turkey. Durham, N.C.: Duke University Press.

Schielke, Samuli. n.d. "Doubt and Unbelief in a Time of Religious Revival." MS.

Schielke, Samuli. 2006. Snacks and Saints: Mawlid Festivals and the Politics of Festivity, Piety, and Modernity in Contemporary Egypt. PhD thesis, University of Amsterdam.

Schielke, Samuli. 2008a. Boredom and Despair in Rural Egypt. Contemporary Islam 2, 3: $251-70$. 
Schielke, Samuli. 2008b. Policing Ambiguity: Muslim Saints-Day Festivals and the Moral Geography of Public Space in Egypt. American Ethnologist 35, 4: 539-52.

Schielke, Samuli. 2009. Being Good in Ramadan: Ambivalence, Fragmentation and the Moral Self in the Lives of Young Egyptians. Journal of the Royal Anthropological Institute 15(s1): s24-s40.

Shryock, Andrew. 1997. Nationalism and the Genealogical Imagination: Oral History and Textual Authority in Tribal Jordan. Berkeley: University of California Press.

Starrett, Gregory. 1998. Putting Islam to Work: Education, Politics, and Religious Transformation in Egypt. Berkeley: University of California Press.

Starrett, Gregory. 1999. Who Put the "Secular" in "Secular State"? Brown Journal of World Affairs 6, 1: 147-62.

Starrett, Gregory. 2006. The American Interest in Islamic Schooling: A Misplaced Emphasis? Middle East Policy 13, 1: 120-31.

Sullivan, Winifred Fallers. 1995. Paying the Words Extra: Religious Discourse in the Supreme Court of the United States. Cambridge, Mass.: Harvard Center for the Study of World Religions.

Sullivan, Winifred Fallers. 2005. The Impossibility of Religious Freedom. Princeton: Princeton University Press.

Taylor, Charles. 2007. A Secular Age. Cambridge, Mass.: Harvard University Press.

Thomas, Keith. 1971. Religion and the Decline of Magic. New York: Scribner's.

Warner, Michael. 2008. Is Liberalism a Religion? In Hent de Vries, ed., Religion: Beyond a Concept. New York: Fordham University Press, 610-17.

Weber, Max. 1946 [1915]. The Social Psychology of the World Religions. In H. H. Gerth and C. Wright Mills, eds., From Max Weber: Essays in Sociology. New York: Oxford University Press, 267-301.

White, Leslie. 1949. Energy and the Evolution of Culture. In The Science of Culture. New York: Grove Press, 363-96.

Winegar, Jessica. 2009. Culture is the Solution: The Civilizing Mission of Egypt's Culture Palaces. Review of Middle East Studies 43, 2:189-97. 